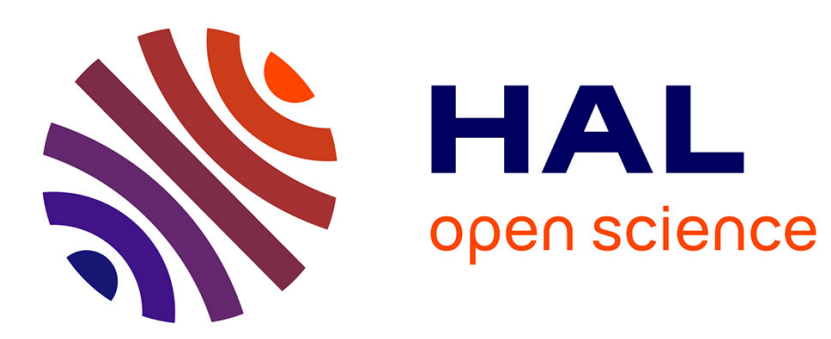

\title{
The Importance of Timely Feedback to Interactivity in Online Education
}

\author{
Esdras Barboza, Márcia Silva
}

\section{To cite this version:}

Esdras Barboza, Márcia Silva. The Importance of Timely Feedback to Interactivity in Online Education. IFIP International Conference on Advances in Production Management Systems (APMS), Sep 2016, Iguassu Falls, Brazil. pp.307-314, 10.1007/978-3-319-51133-7_37 . hal-01615694

\section{HAL Id: hal-01615694 \\ https://hal.inria.fr/hal-01615694}

Submitted on 12 Oct 2017

HAL is a multi-disciplinary open access archive for the deposit and dissemination of scientific research documents, whether they are published or not. The documents may come from teaching and research institutions in France or abroad, or from public or private research centers.
L'archive ouverte pluridisciplinaire HAL, est destinée au dépôt et à la diffusion de documents scientifiques de niveau recherche, publiés ou non, émanant des établissements d'enseignement et de recherche français ou étrangers, des laboratoires publics ou privés. 


\title{
The Importance of Timely Feedback to Interactivity in Online Education
}

\author{
Esdras Jorge Santos Barboza and Marcia Terra da Silva \\ Paulista University, São Paulo, Brazil \\ esdrasjorge@yahoo.com.br
}

\begin{abstract}
This paper discusses the main factors that influence interactivity in online education. The literature points out that time to feedback in education is one of the factors which affect communication among people. Therefore, we did a survey in which participated 67 teachers and 105 students in all. As a result, it was noticed that the level of interactivity students perceived lessens as the time to feedback increases. Also, teachers who give fast feedback review the course as having excellent interactivity. Offering more creative/dynamic activities, giving faster feedback to students, and encouraging students to participate more often in the Virtual Learning Environment are crucial to improving interactivity in Distance Education.
\end{abstract}

Keywords: Feedback · Online Education · Interactivity · VLE

\section{Introduction}

Information technology is a resource of fundamental importance in Online Education. The development of C\&IT favors cheaper and more efficient communication and Education Institutions take advantage of that to increase the offer of Online Education courses. This type of course makes access to education possible to a significative number of students interested in high-quality learning even if they live in remote areas and provide improvements in learning [1]. On the other hand, the experience of learning mediated by technology has been more and more common for students [2]. Therefore, the number of online students has been increasing all over the world [2,3,4]. DEMIRKAN [5], indicated that in 2007, the worldwide number of people taking distance courses had already reached 3.5 billion, with an annual projection of $21,5 \%$ growth. In 2014, in Brazil alone, the number of online students enrolled was above 3,8 millions [6].

Due to the spatial and temporal distance in online education which separates students from their peers and teacher, the learning is influenced by the various elements student/student, student/teacher and student/content. Interaction between the student and the various elements of the course is mediated by the virtual learning environment - VLE of the course and ignited by the teacher $[7,8]$. 
The active role of the teacher is fundamental to the teaching-learning process. The time of feedback is stressed as a preponderant factor for student to feel listened to. Besides, the comments made shall be customized and show constructive criticism $[9,10,11]$.

This paper goes on to identify teachers' and students' opinion about the time to feedback and how it influences their notion of the level of interactivity as well as the advantages and disadvantages of the main VLE communication tools.

\section{Theoretical Base of Feedback}

According to Mory [12], feedback can be described as any procedure or communication held to inform the student about the accuracy of their response, usually related to an instructional question. The feedback can allow the learner to compare their current performance with the standard or expected one, in distance education. Feedback is information presented to the learner after any input in order to shape their perceptions [9].

Feedback is an important element for the learner to regulate learning. The information that is addressed in the feedback interact with prior knowledge, promoting learning $[10,13,14]$. Through feedback participants learn how to behave, interact, speak, reason and do their tasks in the environment in order to be able to achieve the proposed objective [9].

In order to instruct the learner and gradually improve interactivity/learning in Online Education, the time to feedback is one of the factors which need to be analyzed [1]. Must important is the communication aiming the behavior changing or their frame of mind, aiming at an improvement in the learning [15].

\section{$2.1 \quad$ Time of Feedback}

Feedback is useful if it is received after the submissions of the students and before the next activity [16]. If the response time is great, the student may lose interest in the content or feel isolated in the course [17].

In the online environment, giving constant feedback to students is one of the tutors tasks [18]. In distance learning, students feel more isolated because, although there are communication tools in the Virtual Learning Environment they are smaller if compared to classroom learning. Hence, feedback becomes a vital element to consolidate the learning [19].

In order for the tutors to be able to organize their time of work and the consistency of their feedbacks, it is recommended that they access the Virtual Learning Environment (VLE) daily. It is also recommended a pace of response which will not make students wait for feedback for more than 24 hours [9].

\subsection{Concept of Interactivity}

Despite the importance of interaction in distance education, the material studied does not present a single definition of the term. For purposes of this research, 
interactivity is understood as a process of communication between two or more individuals [20], which takes place in a circuit of separate coherent messages which should complete the cycle (to and from the student) [17]

According to the definition of these authors, interaction is an event that occurs between two or more subjects. It may occur synchronously or asynchronously using technology and provision of response or feedback as a result [7].

\section{Method}

This research compares the perceptions of interactivity between teachers and students, as well as elements which influence interactivity such as: time of response and communication media.

As for the technical procedures, the analysis was structured in a survey format, which proved to be more adequate for the achieving the goal of this work.

The data gathering was carried on in two steps with teachers and students. In the first step, students from college education institutions answered to the survey. The conclusion was that in order to improve students' perception of teacher-student interactivity, it is necessary that the response time be less than 24 hours after submissions of doubts, activities or exercises. Above that period, the sensation of isolation increases. In order to improve students' participation in the environment, it was verified that teachers need to constantly motivate students to participate, and take part in forums and chats. Students resents the absence of practical exercises, videos and audiovisual animations for spreading the content in a more dynamic and interactive way [21]. This article continues the initial research band analyze the view of the tutor of Online courses.

In this step, the questionnaire aimed at the tutors of online courses. The tool used was Google Docs, and the form consisted of 21 questions, being 7 multiple choice questions, 9 closed questions and 5 aimed at identifying the teacher's general profile. The form was available at the link: http://goo.gl/ forms/iXTF6ktDQp and the teachers responded to the survey from 03/08/2016 to $03 / 16 / 2016$. To the students, we changed a few questions from the first survey and we provided students with a new form consisting of 20 questions, 6 were multiple choice questions, 5 were closed questions, and 5 were aimed at identifying students' general profile. The form was available in the link: http://goo.gl/forms/PTKKBw7MyU and students answered to the survey from $03 / 08 / 2016$ b to $03 / 16 / 2016$.

The first step 95 students answered the survey. They were from 16 education institutes, 10 were private and six were public. 41 students come from private institutions, out of which 35 were graduation students and 6 were post graduation students; 44 students were from public institutions, out of which 25 were graduation students and 19 were from post graduation students; 10 of them did not inform the kind of institution they are from.

In the second step, the survey was answered by 67 teachers from 44 education institutes, 25 teachers were from private institution, 16 from public institutions 
and 3 did not state the kind of institution they are from. The form for students received 10 valid answers in 10 education institutions, out of which 4 were from private institutions and 6 from public ones.

The main analysis points were the interaction between teachers and students in order to learn the opinion of the respondents as for interaction in the online learning environment, establishing an axis for verification of the hypotheses raised in this work.

The results of this study were analyzed on the following criteria: interactivity as a factor of improvement of learning; effect of interaction between teachers and students in the tasks; and the analysis of the time of feedback teachers give on the tasks/doubts and the degree of interactivity perceived.

\section{Data Analysis}

The data analysis allowed us to evaluate the view of the teacher tutor as for the interactivity and main points to be improved on that matter in Online Courses as well as Online students' point of view.

The respondents were mainly professors from Administration, Graduation, Engineering and Technical Courses, with predominant experience ranging from 4 years.

Points presented as a differential for online students who did not have previous studies opportunity due to their work and time availability were flexibility and reliability, which allow students to get qualified with a better management of time and smaller costs.

The most used Virtual Learning Environment identified in the survey was Moodle $(87,9 \%)$ which is the most popular teaching management system platform, it is open and free, created by Martin Gougiamas in 2001. Teachers and students stated that platforms provide communication tools and those tools are effective in the teaching/learning process, the main used tools being forums, e-mail and chat. The main difficulties addressed in the survey were the sluggishness of the communication tools $41.5 \%$ and the lack of training, besides the fact that the environment shows too much or confusingly displayed information.

It was found that the teacher's perception of interactivity increases along with experience background. Teachers with a 1-to-3-year experience perceive interactivity as below average or good and the more experience ones have a good perception of interactivity in Distance Education.

In the Figure 1 and 2, it can be found that there was a disparity between the answers given by teachers and the students when it comes to the response time and the degree of perception of interactivity. The majority of the teachers stated that they give feedback to students in up to 24 hours, however, students stated that they normally receive feedback from 24 hours on. It was found that the degree of perception of interactivity lessens as the time of feedback increases. The teachers who give fast feedback to students evaluated interactivity as excellent.

On Figure 3, which shows the perception of the degree of interactivity between teachers and students with the factors 1 meaning non-existent and 5 ex- 


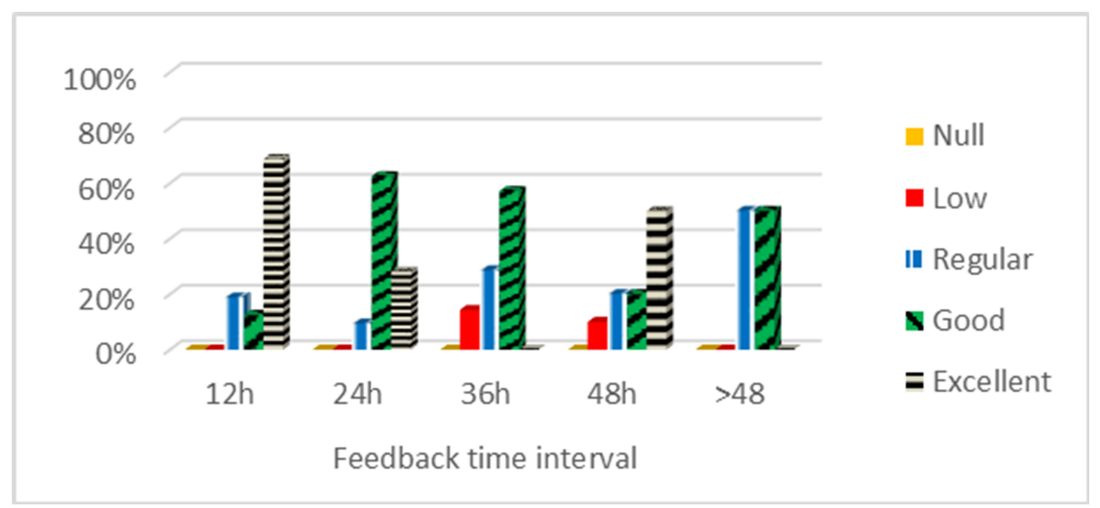

Fig. 1. Time of feedback vs. Degree of perception of interactivity - teacher

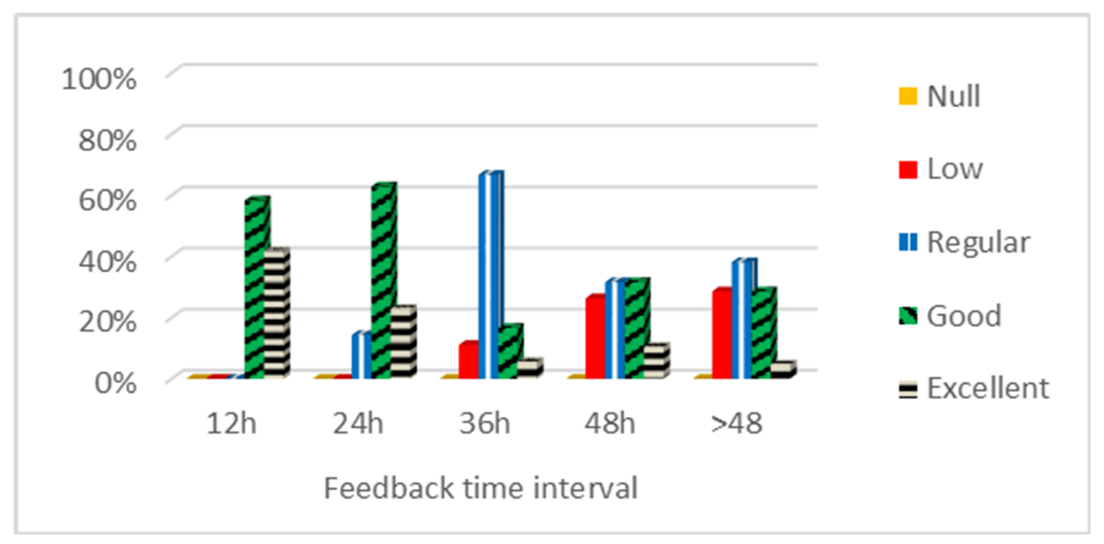

Fig. 2. Time of feedback vs. Degree of perception of interactivity - students

cellent, teachers on average evaluated 4.1, as good and students 3,6 as average nearly good when we analyze a group of students who receive feedback from 24 hours on, the degree of perception of interactivity is reduced to 3.2 , which directly reflects on students' perception of interactivity and, consequently, their interest and development in the course.

According to teachers' comments, the main points presented to improve interactivity were: Offering more creative/dynamic activities 60.9\%; Encouraging students' participation in the VLE 56.5\%; faster feedback to students $53.6 \%$. these comments coincide with students' opinions, according to what was found in the first part of the research [21]. It was also found that in order to have more interactivity between students and teachers, according to students, there should be more encouragement from the teachers to participate in the VLE, faster feedback; previously scheduled meetings in the chats, more constant participation in the forums and easier access to the VLE. 


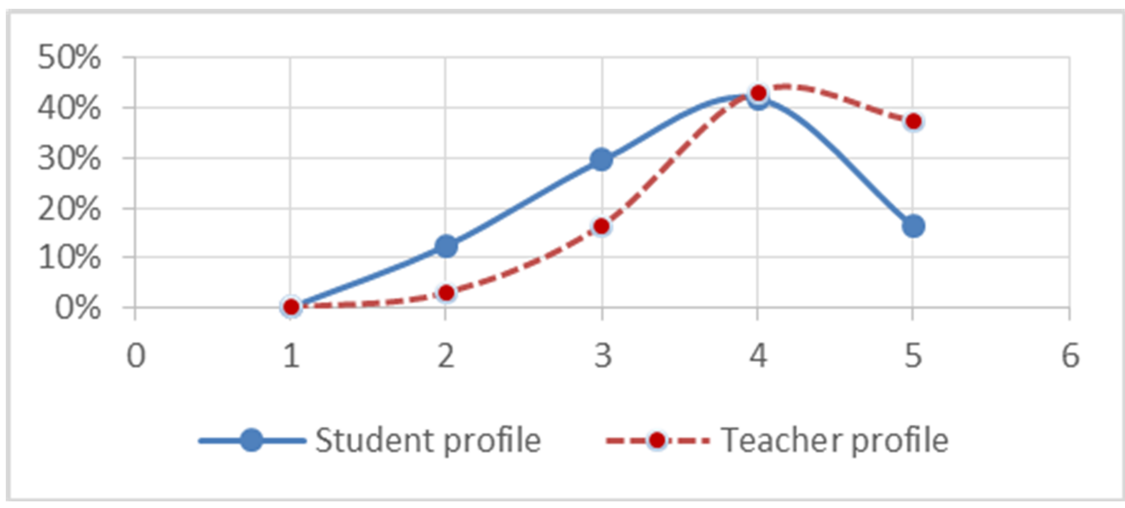

Fig. 3. Perception of the degree of interactivity

Figure 4 is about teachers' encouragement for students to discuss their doubts among them aiming at a collaborative learning in the VLE. The variation between 1-never and 5-always shows that teachers usually tend to encourage students to participate in the VLE (4.4). On the other hand, students state that they are not usually encouraged by their teachers 3,9 .

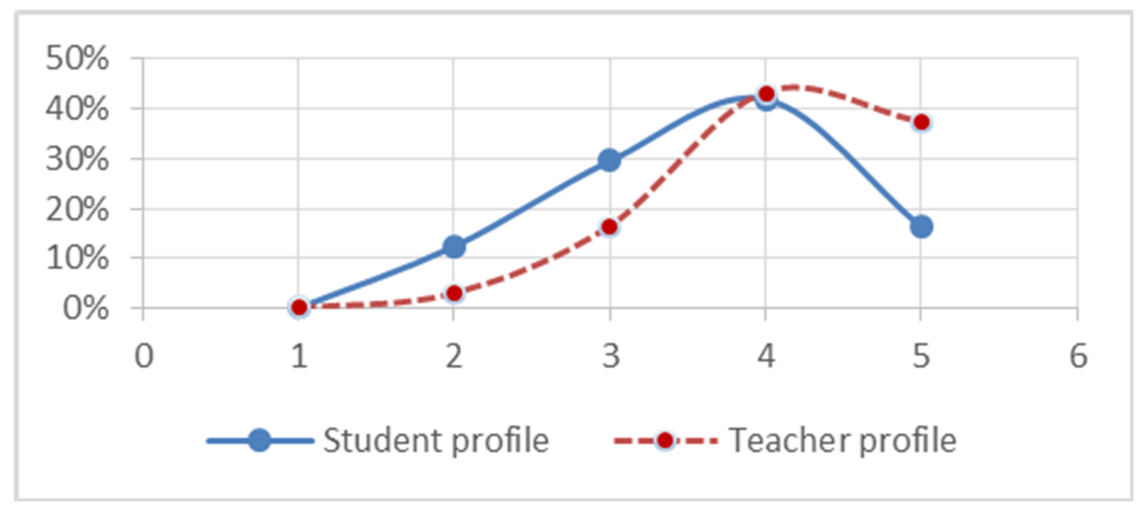

Fig. 4. Encouragement to participate in the VLE

The main points addressed by the teachers which need to be analyzed and commented on by the institutions which offer distance courses are the development of other tasks made by the teachers, the absence of an automatic notification when a new doubt or activity is posted by the students and the 24-hour deadline be considered too short for the teachers. Besides those hindrances, some of the teachers who give feedback in up to 48 hours or above stated that the institution sets that deadline or it is due to the time assigned to tutoring. It is important that the institutions show teachers the importance of the 24-hour- 
deadline feedback for the increasing of students' perception of interactivity in the course, which is a vital factor for these kind of courses.

Besides VLE tools, teachers use Whatsapp 59.1\%, Facebook 59.1\% and other social network as an alternative to communicate with students, such as Skype, LinkedIn, Instagram, Telephone among others. These tools are inserted in the teachers' and students' routine and allow communication to be more dynamic for online students and teachers.

\section{Conclusions}

This research allows us to evaluate the interactivity process between teachers/students, comparing teachers' and students' points of view.

In order to improve interactivity in Online Education it is necessary to have more creative/dynamic activities, faster feedback, more encouragement to participate in the VLE, more adequate communication tools and easier access to the environment. It was found that in order to improve students' interest in the course and their perception of interactivity it is necessary to lessen the time to feedback; previously schedule meetings in the chats; to offer practical exercises and to incentive constant participation in the forums.

It was also found that the degree of perception of interactivity by the students lessens as the time to feedback increases. Institutions could provide teachers with an e-mail automatic notification system or SMS whenever a new doubt or activity is submitted in the VLE., encourage teachers to access the platform on a daily basis, besides assess the time of feedback as a quality requirement for their job.

The main difficulties teachers and students alike have in accessing the VLE should be revised and improved in order to increase the interest and access of distance education students and teachers alike. The main purposes are: to improve the speed of access to communication tools, provide constant training to users, make information in the environment more pragmatic and clearer and make access to the platforms easier.

\section{References}

1. Blasco-Arcas, L., Buil, I., Hernández-Ortega, B., Sese, F.J.: Using Clickers in Class. The Role of Interactivity, Active Collaborative Learning and Engagement in Learning Performance. Computers and Education 62, 102-110 (2013)

2. Henrie, C.R., Halverson, L.R., Graham, C.R.: Measuring Student Engagement in Technology-Mediated Learning: A Review. Computers and Education 90, 36-53 (2015)

3. Garbin, M.C., Garcia, M.F., do Amaral, S.F., da Silva, D., de Abreu, R.R.: Teachers Perception on Collaborative Learning Processes: Experiencing Continuing Teacher Education in Brazil. Procedia-Social and Behavioral Sciences 191, 2231-2235 (2015)

4. Picciano, A.G., Seaman, J., Shea, P., Swan, K.: Examining the Extent and Nature of Online Learning in American K-12 Education: The Research Initiatives of the Alfred P. Sloan Foundation. The internet and higher education 15(2), 127-135 (2012) 
5. Demirkan, H., Goul, M., Gros, M.: A Reference Model for Sustainable E-Learning Service Systems: Experiences with the Joint University/Teradata Consortium. Decision Sciences Journal of Innovative Education 8(1), 151-189 (2010)

6. Associação Brasileira de Educação a Distância: http://www.abed.org.br/ censoead2014/CensoEAD2014_portugues.pdf

7. Joksimovic, S., Gavsevic, D., Loughin, T.M., Kovanovic, V., Hatala, M.: Learning at Distance: Effects of Interaction Traces on Academic Achievement. Computers and Education 87, 204-217 (2015)

8. Tirri, K., Kuusisto, E.: Interaction in Educational Domains. Springer Science \& Business Media (2013)

9. Abreu, D.M., Alves, M.N., et al.: O Feedback e sua Importância no Processo de Tutoria a Distância. Posições 22(2), 189-205 (2016)

10. Gandra, D.C.: A Importância do Feedback na Educação a Distância. Rev. Aprendiz. Em EAD (4) (2015)

11. Hattge, A., Ribas, C., Paulo, A.: A importância do feedback na educação a distância. Revista Eletrônica do Curso de Pedagogia das Faculdades OPET (16), $1-16(2014)$

12. Mory, E.H.: Feedback Research Revisited. Handbook of research on educational communications and technology 2, 745-783 (2004)

13. Ausubel, D.P., Novak, J.D., Hanesian, H., et al.: Educational Psychology: A Cognitive View (1968)

14. Bruner, J.S.: Acts of Meaning, vol. 3. Harvard University Press (1990)

15. Shute, V.J.: Focus on formative feedback. Review of educational research 78(1), 153-189 (2008)

16. Kerka, S., Wonacott, M.E.: Assessing Learners Online. Practitioner File. (2000)

17. Yacci, M.: Interactivity Demystified: A Structural Definition for Distance Education and Intelligent CBT. Educational Technology 40(4), 5-16 (2000)

18. Paiva, V.: Feedback em Ambiente Virtual. Interação na Aprendizagem das línguas. Pelotas: EDUCAT pp. 219-254 (2003)

19. Maia, C., Mattar, J.: ABC da EaD: A Educação a Distância Hoje. Pearson Prentice Hall (2008)

20. Wagner, E.D.: In Support of a Functional Definition of Interaction. American Journal of Distance Education 8(2), 6-29 (1994)

21. Barboza, E., Silva, M.: Technological Development and the Perception of Interactivity for Distance Education (2016) 